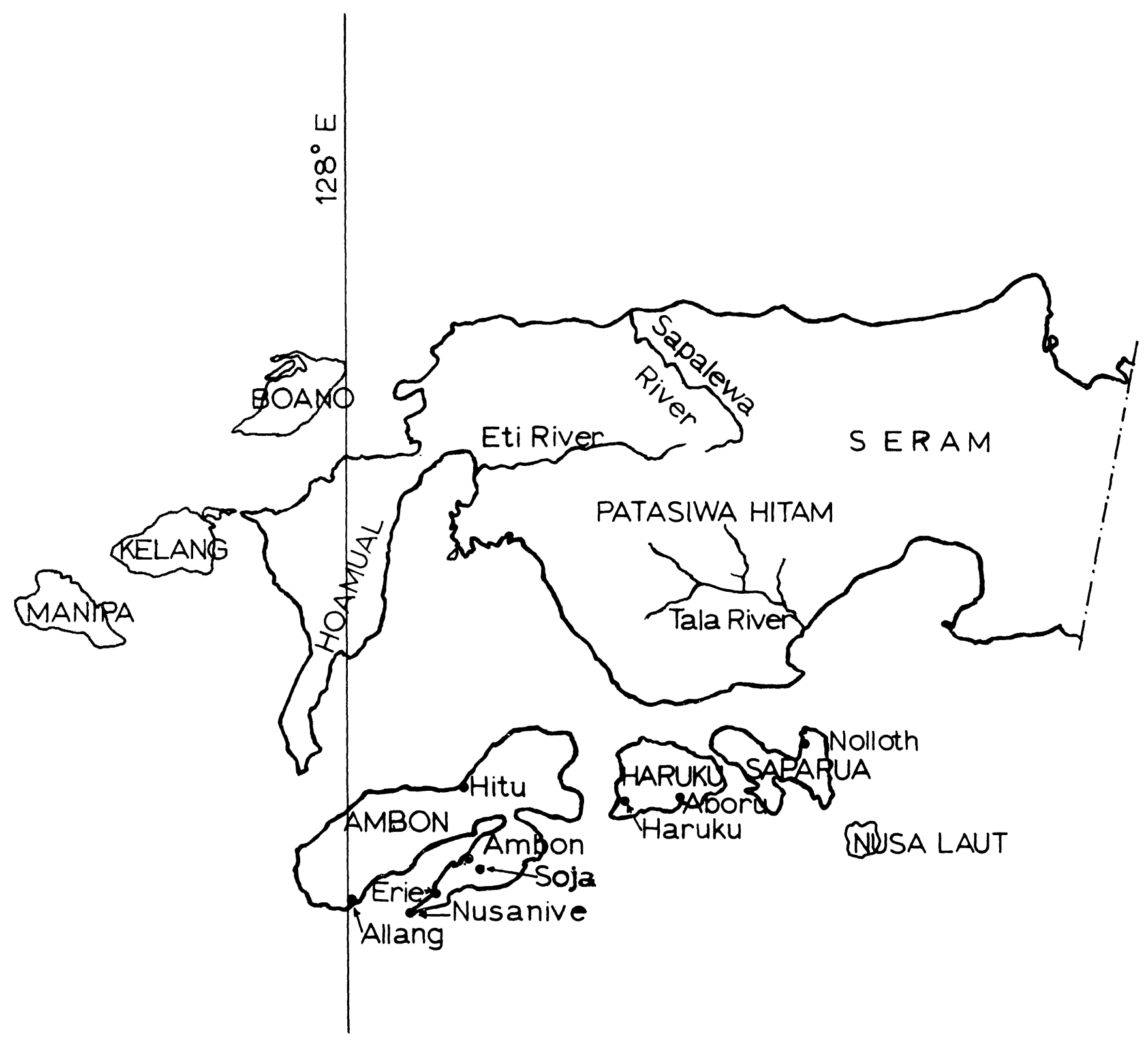


VILLAGE GOVERNMENT IN THE CENTRAL MOLUCCAS*

Rev. Frank L. Cooley

Many diverse influences have fashioned the Badan Saniri Negeri, the village council which constitutes the main institution of local government in the Central Moluccas. The name itself bears witness to the history which has molded it--badan is Malay for a corporate body; sanixi is a seramese term for the council which used to govern the region of the Three Rivers; and negeri is the Malay form for the Sanskrit word nagara, meaning territory, city or realm. ${ }^{1}$ Any attempt to describe the structure

* This paper is a revised version of Chapter III of the author's unpublished doctoral dissertation, "Altar and Throne in Central Moluccan Societies: a Study of the Relationship between the Institutions of Religion and the Institutions of Local Government in a Traditional Society Undergoing Rapid Social Change" (Yale University, 1962). The revision contains the results of recent research undertaken by a team of scholars, including the writer, on the local history of the Moluccas during the period 1475 to 1675. The research is being done under the auspices of the National Cultural Research Institute of the Indonesian Academy of Sciences. The original thesis research was carried out in 1957 and 1960, and was limited largely to Christian villages on the islands of Ambon, Saparua, Haruku and Nusalaut (the last three are now known as Lease, from Uliase). The description of village government presented here is also generally applicable to the Muslim villages, which constitute slightly less than $50 \%$ of the total population of the Central Moluccas and share with the Christians a common physical and cultural heritage.

This paper is largely based on the writer's own field notes and those of Raymond Kennedy, "Field Notes on Indonesia: Ambon and Ceram, 1949-1950, 1955." Kennedy's field notes are as yet unpublished, but are available from the Human Relations Area Files, New Haven, Conn. In addition, two unpublished papers by Ambonese scholars were used: A. N. Radjawane, "The Structure of Village Government on the Island of Haruku," (1956) and a lecture by A. B. Latuconsina to a conference of village heads in Ambon, May 16, 1957.

1. The Seramese terms for negeri are hena or yama. Negeri probably replaced these terms as a result of influences from the western part of Indonesia, but when the change took place is uncertain. One informant suggested that negeri evolved from negorij, a term used by the Dutch East India Company officials to refer to Moluccan villages and employed before in South Africa for the Negro villages there. Radjawane, "The Structure 
and functions of contemporary village government should, therefore, include some account of these influences and how they developed historically.

Within the Badan Saniri Negeri at the present time, one can identify at least four types of offices, each with progressively less political power. Among the first group, are those traditional offices which are still fully functional, such as radja (ruler) and kepala soa (chief of a collection of kin-groups), both of which date back many centuries. At the same level of power, are those non-traditional saniri members who are elected by the people to represent the subdivisions and functional groupings in the village society. The second type consists of traditional officers who retain only a part of their former function, as, for example, the tuan tanah (the lord of the land). Third are those traditional officers whose original functions are virtually obsolete, such as the malessi or kapitan (military commander). Finally, there are certain offices, like the mauweng (a religious official), which are no longer filled and exist only in the people's memory.

There are eight offices represented in nearly every Badan Saniri Negeri throughout the region: the ruler, the soa chiefs, the tuan tanah, the adat ${ }^{2}$ chief, the kapitan, the kéwang, the marinjo, and the ordinary elected members of the council. But this present constellation of offices only developed gradually over time.

The earliest known political units were fairly simple communities composed of a small group of migrant families settling in a particular location, probably before $1450 \mathrm{~A} . \mathrm{D}$. Each of these earliest settlements was headed by an upu, who was responsible for all matters related to the temporal world. In military matters, he was assisted by a malessi. Religious affairs and relations with the powers inhabiting "the other world" were conducted by the mauweng and his adjutant, the malimu or maitalé.

The upu, theoretically, was a descendant of the leader of one of the soa, the early migrant groups. ${ }^{3}$ Eventually, two or

of Village Government," P. 1. A Dutch dictionary identifies the word negorij as the East Indian term nagaree, but also gives the word negerij, meaning "Negro village," and coming from the root neger, Negro. Engels Woordenboek (Groningen: Wolters, 1959), p. 550 .

2. Adat, as used in this paper, refers to the structured norms underlying the conventional personal behavior and customary law governing actions of individuals and groups.

3. Originally, soa seems not to have been a lineage group but more an ad hoc term for an inter-related migrant group. See also below pp. IUIff. The etymology of the term soa remains 
more such family groups joined to form small settlements called aman. " The aman was a settlement somewhat smaller than the later-formed negeri, and, in those days, the soa were also much smaller than at present. They included only the mata rumah asali, the patrilineages which had come in the first migration. other patrilineages (mata rumah) were added to the soa later.

In the process, a single leader, the latu, emerged from among the various chiefs (upu) of the smaller groups (soa). The other leaders became his assistants, but were still responsible for their own original group. The first patrilineage to arrive continued to be distinguished in special ways and its leader to be known by the title tuan tanah, even if it was eventually superseded by another patrilineage in the position of top leadership. Three offices found today resulted from this development, namely, latu, kepala soa, and tuan tanah.

Another development, caused by the growth in the size and power of the settlement, was a differentiation of functions. It seems likely that, in the original soa, all functions were held by the upu, who served as king, priest and battle commander, and who probably became the leader precisely because he was believed to possess special abilities and powers in these crucial spheres. Legends about the earliest times relate numerous events in which these qualities were manifested, to the great advantage of the community. But, as the population increased, groups became more complex and territorial control expanded. It became necessary for the upu (now called latu) to delegate some of his powers to others who probably already acted as his assistants, but were not recognized as holding separate offices. These offices developed in the functional spheres of administration (latu, kepala soa, marinjo, alamanan), religion (tuan tanah, mauweng, ma'atoké), war (malessi) and land affairs (kepala dati and kéwang). ${ }^{5}$ There is some evidence that from the time the present negeri were established until

uncertain. The indigenous term in Allang is urur; in Erie, antoun; in Waraka, South Seram, it is nurua. Allang informants atributed soa to the Hoamual, West seram dialect. others attribute it to the North Moluccas.

4. Aman (with amang and amano as variants) is derived from the indigenous term ama, meaning "father" or "lord." An aman was a settlement ruled by or belonging to an ama. Soja was said to have consisted of nine aman, the locations of which are still remembered. Aboru claimed to be composed of 99 aman, but when asked to list them, the village council members could only remember 23 names, and there was disagreement about many of them.

5. See also: Kennedy, "Field Notes, 1955," p. 79. The kepala dati is elected from within the patrilineage to determine the distribution of patrilineage-held land and its produce. 
around the end of the nineteenth century, there were similar offices attached to each soa--kepala soa, mauweng, malessi, alamanan, and marinjo--but of these only the first and last remain today.

As the population continued to grow and the villages to expand, the aman began to coalesce into federations called uli. These aman were located in the hills, two or three kilometers from the shoreline. The dominant aman in each uli came to be called, and is so even today, the negeri lama or "old village." The negeri lama is the village in which the mata rumah radja and mata rumah tuan tanah are located. The uli usually contained five or nine aman, with the strongest ruler and aman predominating and providing the federation's chieftain, the radja. The constituent villages were headed by lesser rulers called patih or orang kaja. The uli certainly predated the arrival of the Dutch in 1605, and perhaps even that of the Portuguese in 1512. Most likely, the federating process occurred as the result of powerful alien groups moving in from Java, the Celebes or even the North Moluccas. These groups were able to subjugate the Central Moluccan populations because they possessed more advanced weapons and skilis. The ruling patrilineages in several of the more important villages, such as Hitu, Nusanive, Soja, Aboru, Tulehu, claim relationships with, if not direct descent from, ancestors who originated in eastern Java or southern Celebes.

Thus, by the time the Europeans appeared, the basic system of government as it exists today had already developed. It was primarily Seramese in pattern but with important additions introduced from other regions. The coming of the Europeans and the establishment of colonial rule, brought new forces into play. The Dutch destroyed the uli system and replaced it with autonomous villages directly subject to Dutch East India Company officials. They worked to break the federations into smaller units and thereby weaken potential centers of resistance. In addition, such small units were more easily manipulated to achieve Dutch economic aims, notably a monopoly on the spice trade, and to secure an orderly and obedient subject population. The realization of these aims required at least fifty years, only nearing completion in the latter part of the seventeenth century.

During the general dislocation and instability which characterized the period of village formation (roughly 1480 to 1660), the aman disappeared. Today only the soa and the mata rumah remain in the structure of village government. There were several fierce wars in various parts of the Central Moluccas between groups within the region in which outside forces, including European states, were periodically involved. A general upheaval was caused by the move from the hills to the shoreline. Some mata rumah, and even soa, within an aman were either liquidated 
or banished to other places as a form of punishment. ${ }^{6}$ The Dutch Governor at Ambon led hongitochten (punitive expeditions) against recalcitrant settlements. The expeditions were transported by cora-cora (war canoes), requisitioned from the villages and manned by villagers. The degree and quality of participation by the villagers in these expeditions determined Dutch rewards or punishments, which, in turn, effected changes in landownership or land-holdings, ruling patrilineages and the ranks of village rulers. In addition to war, the coming of Islam and Christianity undoubtedly caused a certain number of groups to move voluntarily, as when religious differences split a particular village into two or more groups.

\section{Offices of Village Government}

The Dutch retained the earlier pattern by dividing the rulers into three ranks, with the radja as the highest. In those villages which had been the chief settlement of the uli, the title of radja was continued even though the ruler no longer exercised jurisdiction over the other villages. Although today the village chief is usually referred to by the general title of pemerintah negeri, literally "government of the village," the villagers almost always address him as Bapak Radja. The term radja is actually of Sanskrit derivation and was probably introduced before the Dutch arrived. The indigenous term, latu, is still preserved in titles and often used in ceremonies. The other two ranks of village ruler were the patih and, at a slightly lower level, the orang kaja, meaning "man of high position."

6. This happened in Allang in the second quarter of the seventeenth century, and almost certainly in other villages as well.

7. Allang elders reported that, before the village accepted Christianity in 1622, part of the people were Muslims and the rest Alifuru. Some from each group may have left rather than accept conversion.

8. The terms patih and bupati, signifying administrative offices, are common on Java. Patih, in the Moluccas, is clearly a loan word from Javanese and perhaps is rooted in one of the Indian languages. In the glossary of Kennedy's "Field Notes," (not composed by Kennedy himself), patih is identified as an Ambonese word, but this is wholly unconvincing.

The Kennedy glossary states that orang kaja is a higher rank than patih, the latter being defined as the "third rank in the noble hierarchy." I can account for this only by assuming that the compilers of the glossary were not familiar with the details of Moluccan society. My informants unanimously ranked patih second and orang kaja third. The title orang kaja is Malay and was already employed in the region around 
The Dutch colonial government presented the radja, patih and orang kaja each with a kepala rotan perak (silver-headed baton) as a symbol of their formal installation and their political authority. After some years of service, a radja's increased status was symbolized by a tongkat mas (gold-headed baton or staff). The patih or orang kaja might also raise their respective positions by performing some unusually meritorious service for the colonial government.

These differences in status, however important to the individual involved or to colonial protocol, were not significant within the village. The orang kaja and the radja apparently had the same status relative to their respective peoples. Each was the top man in a particular village--the most respected, the most feared and the most powerful. There seems to be no evidence that these differences in rank between village chiefs existed in indigenous Seram society. This suggests strongly that the uli system was introduced to Ambon, and perhaps Lease, by immigrants from other parts of Indonesia. The occurrence of the term patih strengthens this hypothesis.

The village ruler usually comes from the highest level of the village aristocracy. The position tends to be hereditary. In earlien times, the eldest son of the radja normally succeeded his father, unless he was clearly incapable. The father apparently made the choice and prepared the "crown prince" for his future role. The village council approved the choice and installed him after his father's death. In more recent times, it has been generally understood that the radja must come from one among a group of specified patrilineages, ${ }^{9}$ which are considered to have the hereditary right and traditional responsibility to rule. In most villages, there are at least two clans with this prerogative, the clan in power before colonial rule and the clan elevated to power by the Dutch. ${ }^{10}$ In

Malacca when the Portuguese captured that city in 1511. It is generally used for village heads in the Central Moluccas in both the earliest Portuguese reports and in Ridjali's Hikajat Tanah Hitu. This latter work was composed around 1650 in the Malay language but in the Arabic script, probably by a native of Ambon island. It is the earliest written source on the region by an identifiable native author.

9. This is an abbreviated form of the technical kinship term preferred by Koentjaraningrat, Villages in Indonesia (Ithaca, N.Y.: Cornell University, 1967), p. 141. In other publications the writer has usually used the term clan or patriclan following Murdock, Social Structure (New York: Macmillan, 1949), Pp. 63-69.

10. In several villages the following tale was related concerning these circumstances. The ruler would be summoned from the negeri lama in the hills to meet the Dutch or Portuguese commander. He would be too afraid or too proud to go himself, 
a number of villages, however, only one clan (mata rumah) has ruled as long as anyone can remember. Other villages have experienced periods when rule was usurped by persons who had no hereditary right to it. In such cases, one often hears accounts of misfortunes which befell the usurper's family and the village. The belief is prevalent that the specified descent-group's prerogatives are consonant with adat, and anything which deviates from the adat is fraught with danger.

Formerly, the radja was truly an absolute ruler, more to be feared than respected. He represented all the power of the ancestors, in whose line he stood and in whose name he governed; he also had great temporal power because he was backed up by the colonial regime. Under the Dutch East India Company, the village ruler was virtually a law unto himself, so long as he satisfied the demands of company officials. The colonial system depended on securing the cooperation of local rulers so that the desired goods and services would be forthcoming at little cost to the Dutch government. In the Central Moluccas, as elsewhere, various perquisites were given to the pemerintah negeri. The ordinary villagers were required to render personal services, called heerendienst (service to the lords), to the radja and his wife. ${ }^{11}$ The Dutch also provided the radja with an annual payment (called nahosi) in the form of commodities. It was considered as compensation for the personal loss he had sustained by the requirement that all spices be sold directly to the government. Previously the villagers had paid a portion of their annual crop to the radja. ${ }^{2}$ The village

and an assistant, in some cases a marinjo, would descend, with the result that the latter was recognized as ruler by the foreign power.

11. Each week or month, a specified number of young men, usually from five to eight depending on the size of the village, were assigned to work for the radja, mainly cultivating his extensive lands. These men were called kwarto, probably from the Portuguese term which indicates the division of ordinary seamen into ship's watches. The young women, called hakakil, served in the house, assisting the radja's wife. The system was abolished in 1920 , because the rights of kwarto and hakakil were frequently abused. It was replaced by payment of a monthly stipend to the village ruler. The stipend was in fact sufficient to meet the ruler's living expenses for only about two weeks.

12. According to one village ruler, the nahosi included: several boxes of red powder for use in the tjakalelé dance, mirrors

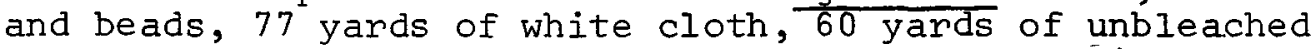
cotton stuff, seven bolts of 30 yards each of denim, and twelve 12-yard bolts of red cloth (kain berang), used in ceremonial costumes. 
ruler also received a 200-guilder bonus for each young man from his village who entered the colonial army. ${ }^{13}$

None of these perquisites remains today, but all are remembered, at times with some nostalgia, in view of the meagre remuneration now given to village rulers. In 1960, for example, the remuneration was a cash "stipend" of 200 rupiah per month-not a "salary," it was emphasized, for the radja is not a civil servant but the head of an adat community. At the official rate of exchange, this amounted to slightly less than $\$ 5.00$, and only about $\$ 1.00$ at the "open market" rate. Yet the custom of presenting the radja with gifts in kind from the sea, or from gardens and groves, when the harvest is good, is still generally followed and is a manifestation of his status as head of the adat community.

The present role of the pemerintah negeri is more like that of a president than a ruling monarch. He is the head of a government, a chief executive with administrative assistants; in general, the notion of special powers attached to the person of the radja has disappeared. He is elected to the office by the villagers, and his rights and duties are more clearly defined and limited than in pre-Independence days. Since 1950, the authority of the village government itself has been whittled away, and the office of ruler has suffered from this reduction in power and prestige.

The kepala soa ${ }^{14}$ serves as principal assistant to the village ruler. The number of soa in a given village may vary but, generally, there will be at least two: ${ }^{15}$ Aboru, with a population of nearly 2,300, has five soa; Allang, with approximately 2,800 inhabitants, has eight; Erie, with 600, has four; Naku, with 700 , has three; and Soja, with 715 , has two, at present.

What information is available indicates that the soa, in more or less their present form, date from the settling of each village at its present location.

It is possible that at a very early time the soa may have been a kin-group. ${ }^{16}$ Sometimes rumah tau coincides with soa,

13. The family of the boy received 250 guilders. Later these amounts were reduced to 50 guilders for the ruler, and 60 for the family.

14. The indigenous term is mutuaella, according to Kennedy, "Fieldnotes, 1955," p. 117.

15. The writer personally knows of no case where there are more than eight, though such may exist, especially among the larger Musiim settlements.

16. Kennedy so identifies it in two places: Field Notes on Indonesia: S. Celebes 1949 (New Haven: Human Relations Area Files, 1953), P. 256, and also "Fieldnotes, 1955," on Ambon, P. 345 . 
and rumah tau (or Iumatau) is the indigenous term for the uniIineal descent group, the mata rumah. If the historical identification of rumah tau with soa could be established, which the writer thinks highly unlikely, then soa would definitely be a kin-group similar to a clan. Confused interpretations of the term soa may have arisen from a mistaken identification of the soa with its central rumah tau, the patrilineage around which it was formed and which holds the hereditary privilege of ruling it.

Reports that at one time land was soa-controlled (that all dati-dusun were held and administered communally by the soa) may also imply that the soa was originally a kin-group. One of the main functions of unilineal descent groups is the control and administration of land. But it is conceivable that land may have been held communally by the soa, without the soa necessarily having been a kin-group, prior to the disruptions caused by the Dutch between 1620 and 1680. It is fairly certain that harsh Dutch policies for controlling the spice trade not only shifted the locus of clove production, but also radically altered the pattern of land-holding and land-ownership in the Central Moluccas. ${ }^{7}$ Private or patrilineage land-holdings seem to have developed under the system of intensive spice production instituted after the Dutch supplanted the Portuguese in 1605.

Whatever the case, it seems clear that from the time the villages were established in their present locations, the soa has not been a kin-group but rather a collection of kin-groups, and that the social etructure of the soa and the villages has remained more or less fixed. The only changes have been the addition or elimination of certain soa, as a result of colonial policy or shifts in population. Aboru and Erie, for example, have added soa; whereas, in Soja, some soa have died out.

It is sometimes stated that the soa is a geographic subdivision of the village. ${ }^{18}$ In Allang, for instance, the term soa is indeed used ambiguously, and it would be easy to conclude that the eight soa are districts or wards within this rather large village. Careful study of the available data, however,

17. Cooley, Ambonese Adat, A General Description (New Haven: Yale University, 1962), p. 58 .

18. For example, Kennedy, "Fieldnotes, 1955," p. 256. There are two possible interpretations which would allow one to describe the soa as a geographic unit. One we have already considered and concluded to be exceedingly unlikely, namely, the idea that a soa was a kin-group and therefore a landadministering unit. In this case its land would very likely have been localized in one district. The other possibility is to identify aman with soa, which Kennedy seems to do in his "Fieldnotes, $1955, " \mathrm{p}$. 333. Since an aman was a geographic unit, a soa would naturally be so too. The writer sees no evidence for this assumption. 
makes it clear that this meaning of the term is derivative and applies only to this village. Even in Allang, the basic meaning of soa remains a fixed grouping of patrilineages presided over by a chief or headman, who assists the village head. While soa may thus have geographic connotations in a few places, it basically refers not to geographic locale but to lineal descent. Soa are collections of unilateral descent groups, mata rumah, which became established at a particular time. They were, in some cases, enlarged by the addition of new immigrant patrilineages; in other cases, they shrank, when certain mata rumah died out. Some soa may have completely disappeared for the same reason.

The kepala soa belongs to the lesser village aristocracy and is selected from among qualified candidates belonging to a specific clan. As with the office of radja, the kepala soa, in former days, was the eldest son of the preceding incumbent. In recent years, however, the office has become elective. Adult members of the soa (the anak-anak soa) nominate the candidates, whose names are then submitted to the entire village electorate. Election by the village rather than by the soa has been instituted because when the kepala soa serves as officer-of-the-month (kepala soa djaga bulan), his jurisdiction extends over the whole village.

There are generally two categories of kepala soa. Kepala soa akte are soa chiefs who have been approved and installed by the district government, and who receive a small remuneration for those months in which they serve as kepala soa djaga bulan. They have official status, and, therefore, are somewhat more respected by the villagers. The kepala soa tanah or kepala soa masing are soa chiefs elected according to village traditions, but not recognized or installed by the district government. They have particular functions in matters of land (tanah) or adat, which give them the title of kepala soa, but they do not rule over a soa in the same way as the kepala soa akte, nor do they serve as officer-of-the-month. They receive no remuneration from the civil administration. The kepala soa serve as members of the Badan Saniri Negeri and have relatively high status in village society, though well below that of the radja. Because the functions of soa head are essentially administrative and do not involve much contact with supra-village authorities, the office has perhaps been less influenced by outside forces than that of the radja, or other offices related to religion or adat, such as mauweng and tuan tanah.

Tuan tanah has been translated as "lord of the land."19 Sometimes the titles tuan negeri or tuan adat are used, but tuan

19. There are various indigenous terms, all of which roughly mean the same thing: amanopunjo, amanapui, amanupui, latunusa. 
tanah is the most exact and most widely applied. This office is filled by a hereditary descendant of the first ancestor to settle in the area, probably in many cases the first upu. It often happened that the lineage of this upu was later politically superseded by a newer lineage, which then assumed the title of latu or radja. This defeat, however, did not affect in any way the earlier lineage's special jurisdiction over the land of the village and their rights and responsibilities in closing and opening the sasi, ${ }^{20}$ healing infirmities believed to be caused by contact with tabooed places and objects within the village, or administering oaths. With the fading of traditional beliefs, the actual functions of the tuan tanah have noticeably declined. Yet in most villages today the office is still filled, and the tuan tanah performs at various ceremonial occasions involving the whole village.

The tuan tanah, like the radja, is ranked as a member of the upper village aristocracy; both are connected by descent to the original founders of the village. The tuan tanah does not enjoy as high status as the radja because he has lost much of his functional significance. The position is still filled in the traditional way; the incumbent tuan tanah trains his eldest son in the necessary lore, knowledge and skills. If the eldest son is not interested, does not stay in the village, or is not capable, another is chosen and prepared to assume the office when it falls vacant. In some villages there is more than one tuan tanah, because there was more than one patrilineage in the first immigrant group, and it is believed that the original conditions must be maintained.

The kepala adat (adat chief) is the present-day heir of some of the functions of the mauweng, a position no longer found in Moluccan villages. The mauweng (or mauwen, maueng) was the main functionary in the indigenous religion, especially serving as priest of the secret religious society (Kakehan) into which all male members of Patasiwa Hitam were initiated when they reached adulthood.2 The Kakéhan house, or temple, where the mauweng

20. Sasi is a closed season declared on products of the sea and land, if deemed necessary in the interests of conservation. Cooley, Ambonese Adat, pp. 77-80.

21. These are particular institutions within the over-all indigenous religious system that seem to have characterized Seramese society. The movement of populations from seram to Ambon-Lease perhaps preceded the coming of Is Iam and Christianity by only a short period of time. Hence the main institutions of the indigenous religion were not yet deeply implanted. For this reason, both Islam and Christianity were much more quickly and easily accepted in Ambon-Lease than in the interior of Seram, in Buru or in the Southeast Moluccas, where the was much more resistance to all missionary efforts. 
officiated, was located in the forest, at some distance from the village. Apparently, each soa had a mauweng, who was responsible for all matters connected with the "other world," including both religion and adat, which, prior to the coming of Christianity, seem not to have been significantly differentiated. This is why the kepala adat has succeeded to part of the mauweng's functions and position. ${ }^{2}$ The mauweng also practised the art of divination, determining events which had occurred in some distant place on would occur in the future, in order to protect or advance the welfare of the village. The usual methods of divination were the examination of the entrails of fowl or animals, cutting ginger root or coconuts, or using the ricesieve and a pair of scissors.

The kepala adat in present Ambonese society is the person (sometimes there are two) who is the expert on adat requirements and ceremonies. He is appointed by the radja and approved by the Saniri. Usually, however, like the older mauweng, he is the son of the previous incumbent, who has learned from his father all the lore and secret knowledge essential to his position. He belongs to the lower village aristocracy and is much respected and feared, especially by the young, because he is believed to have a special relationship to the powers of the other world.

The kapitan, ${ }^{23}$ in the indigenous language termed malessi was also referred to as the kepala pasukan (leader of the forces), or the panglima perang (commander in warfare). In the early days, when there was much internal warfare between villages, and when raids by outsiders in search of slaves or other valu$\mathrm{able}$ goods were still frequent occurrences, the office of malessi or kapitan was vital to village security. ${ }^{4}$ This office seems to date from the original differentiation of functions alluded to above, by which particular offices were established to meet specific needs. Originally, the kapitan seems to have been appointed by the upu latu for his prowess in warfare and magic. The position later became hereditary, with the old kapitan teaching one of his sons the strategy and skills of warfare, as well as the secrets of magic and ritual.

22. The other part of the religious function and position was taken over by the tuagama, who in the days before most village Protestant congregations were served by ministers or "teacherpreachers," guru djemaat, was the main religious functionary in Christian villages.

23. The name of this office changed from the indigenous term to this Portuguese word some time after 1512 .

24. Kennedy has pointed out that it seemed as if every village had had at least one traditional enemy. See his, "Fieldnotes, 1955," PP. 307-308. 
The kapitan was responsible for planning and leading military operations, whether offensive of defensive. He was believed to possess magical powers which rendered his person invulnerable to weapons, and guaranteed the success of the foray, provided the required ceremonies were properly performed. These rituals included the killing of fowls, the waving of weapons through the heat and smoke of particular types of burning wood, the wardance (tjakalélé), and the recitation in the indigenous tongue of formulae for summoning the ancestors and threatening the enemy. ${ }^{5}$ Knowledge of these ceremonies is found today in only a few villages.

In some villages there were two kapitan. One had primary responsibility for the defense of the coastal area against attack from the sea; this accounts for his title, Kapitan Laut (Captain of the Sea). The other, sometimes referred to as Kapitan Darat, (Captain of the Land), was charged with resisting all attacks from the "rear" or landward side. The hill villages would probably have only one kapitan. With the consolidation of Dutch power in the Moluccas, the region was pacified and there was an attendant reduction in both internal conflicts and raids from outside. As a result, there was less and less occasion for practising the art of warfare on the village level. The kapitan and malessi consequently had little to do, and gradually the positions disappeared for all but ceremonial functions. The malessi finally disappeared altogether. Only the kapitan still remains and he retains only a shadow of his former duties. The office exists in most villages, but its only remaining functions seem to be ceremonial, such as the renewing of péla bonds, ${ }^{26}$ and leading the war-dance (tjakalélé) on occasions of special significance. The kapitan is not considered a regular member of the Badan Saniri Negeri, but, on occasion, he may be invited to sit with the council. He is a highly respected and feared member of the community because his hereditary position connects him with the early ancestors of the village, and especially because he is believed to be the heir to their magical powers.

The kéwang acts as the village police or security force. There are two classes, the ordinary kewang numbering as many as 20 or 30 in larger villages, and the kepala kéwang, who is selected by the ruler with the approval of the saniri, and who is responsible for the kewang forces. One informant suggested that the kéwang were selected from the kepala dati, or dati chiefs, since this group is most intimately acquainted with the details of land-boundaries. The main function of the kéwang is policing

25. For a description of this performance see, Kennedy, "Fieldnotes, 1955."

26. Cooley, Ambonese Adat, pp. 71-77. The péla are ceremonial bonds of friendship and mutual obligation between villages. 
garden and forest lands to protect them from encroachments. The kéwang's other résponsibility is the supervision of the sasi, to which reference has previously been made. The kéwang are appointed from among the orang biasa (commoners) and have no particular status within village society. The kepala kéwang, although not usually a member of the saniri, may be asked to attend when questions within his jurisdiction are discussed. The office still has real functions, even though it has lost some of its importance with the decline of the adat sasi.

The office of marinjo appears to have a long history, dating from the time when government was only beginning to show signs of differentiation. The marinjo was originally one of the kapitan's assistants, a spokesman who transmitted the ruler's instructions and decrees to the people, acting as mulut radja, literally "the radja's mouth." 27 Probably because of his close association with the radja, the marinjo enjoyed considerable prestige in village society, even though he did not belong to the aristocracy and held no hereditary position. Later, he became the assistant of the soa chief and served as an adjutant or general errand-boy of the kepala soa during the month when that notable was on duty as the radja's "prime minister." Today, the marinjo is appointed by the saniri. He receives a tax exemption as remuneration for his services, and enjoys a status somewhat higher than that of the common people from whom he is chosen. In addition to his official duties for the village government, he is expected to perform personal services for the radja and the soa chief on monthly duty.

The final office in village government is that of the elected member. During the $1920^{\prime} \mathrm{s}$, the Dutch, in response to the pressures of nationalism, instituted the practice of including elected members on all government councils. These elected members were of lower status than the traditionally-determined members. In the Moluccas, one representative was elected from among the commoners for each soa. In some cases, those elected held a special position within their own soa. They might be kepala dati or kepala rumah tau, but on the saniri they sat as elected members reflecting the opinions of the people. The elected members now enjoy a status higher than that of the marinjo, but not equal to that of the lower aristocracy. Within the saniri, they may have special responsibilities for some segment of village life, such as roads and transportation, or youth activities.

Two offices formerly connected with the village government no longer exist, except in the memory of a handful of the oldest

27. He was called maitalé in one of the dialects. Variant terms are malimu and marimu. The present title, marinjo, was introduced after 1512 and derives from merinho, the Portuguese term for the corresponding office. 
inhabitants. The incumbents of these offices, in all likelihood, were at one time considered members of the saniri, but they seem not to have had high status in the village. ${ }^{2}$ The first of these was the alamanan or alamanane, defined by Kennedy as a "spokesman in the saniri council." Apparently each soa was entitled to have one alamanan on the saniri. Perhaps he was the forerunner of the modern elected saniri members who supposedly represent the soa members. More likely, however, he was an officer with special rights and responsibilities in matters involving adat, particularly when the saniri, or part of it, sat as a judicial court. The alamanan may have been the spokesman-in-court, with particular responsibility for cases involving his own soa. The withdrawal of judicial functions from the saniri may, therefore, account for the disappearance of this position.

The other office which has also long since disappeared in most villages, is that of the ma'atoké, whom Kennedy describes as the custodian of the baileu, ${ }^{29}$ charged with the responsibility of keeping the baileu clean and in order, and notifying the radja of needed repairs. Kennedy reports that there was one ma'atoké for each soa. ${ }^{30}$ The Radja of Elpaputih, one of Kennedy's main informants in 1949, described the ma'atoké to the present writer in 1960 as "the ruler of the baileu, the person responsible for officiating at ceremonies held there." This description does not accord with other information, which suggests that the tuan tanah and the kepala adat officiated at baileu ceremonies. Kennedy's description of the ma'atoké's function seems more acceptable, since other informants noted that in the earliest days, when families first came to the village, the radja assigned certain duties, in return for which he granted them land. Included among these duties were the care and repair of the baileu, which constituted the office of the ma'atoké. The office no longer exists today, perhaps because the baileu, as an institution, has itself all but disappeared.

\section{The Structure of the Village Council}

The government of the village is carried out by three concentric institutions all bearing the title saniri. They are the Saniri Radjapatih (Council of the Radja and his Assistants), the

28. One of these offices was encountered only once by the writer, on his second visit to the region, but was reported to Kennedy, especially in his researches in the region of Elpaputih in South Seram. Kennedy, "Fieldnotes, 1955," pp. 140, 179, $184 \mathrm{ff.}$

29. The village adat-house; see Cooley, Ambonese Adat, pp. 8-13.

30. Kennedy, "Fieldnotes, 1955," pp. 179, 184. 
Saniri Negeri Lengkap (Complete Village Council), and the Saniri Negeri Besar (Great Village Council). There are minor variations in terminology in different villages, but the general pattern applies to the entire region. It is widely believed that the structure of government in the Central Moluccas is patterned after that found originally on Nunusaku, the legendary mountain in West Seram, source of the Three Rivers, the Eti, the Tala, and the Sapalewa, and traditionally regarded as the beginning and the end, the source and the destiny of life. It will be useful, therefore, to indicate what is held to have been the structure of government in indigenous (Alifuru) Seram society. The Three Rivers region was divided into three adatareas, one for each river. Throughout the region, each village had a council of its own called the saniri. Its most important members were the saniri chief (kepala saniri), for civil administration, the mauweng, for religious affains, and the kapitan for matters of war. There appears also to have been a larger body, which met to consider matters affecting the welfare of the people of each River. It was composed of all the saniri chiefs, mauweng and kapitan of the villages within that area, and elected three chief officials, called latu inama. On occasion the three top officers from each River met in a supreme saniri; the nine members reflected the fact that this is the Patasiwa region of Seram, where the number nine has special significance. ${ }^{31}$

As we have seen, the mauweng and the kapitan have, for all functional purposes, practically disappeared. The core of the Badan Saniri Negeri on the village level, therefore, is the Saniri Radjapatih, which consists of the village ruler (radja) and his assistants. This is a small group, usually about six persons, and it is the administrative body of the village council. It can be called the executive branch of village government, bearing in mind that there is a still smaller executive unit consisting of the radja and the kepala soa djaga bulan, together with their marinjo. Intemal matters of importance and all affairs related to the outside world are referred to the radja for decision and action. When he deems it necessary, he summons the other soa chiefs for consultation and decision by beating the big drum on his porch. The Saniri Radjapatih is, for all practical purposes, the most important part of village government. All members of this body are chosen according to lineage, and they are the traditional leaders of the village.

The Saniri Negeri Lengkap is composed of the Saniri Radjapatih plus the co-opted and elected members referred to in the preceding section. This is the legislative body of village government. It discusses matters of larger importance,

31. Kennedy, "Fieldnotes, 1955," p. 184. 
makes policy decisions and issues regulations. In addition to the members of the Saniri Radjapatih, it includes both traditional leaders, such as the kepala adat, tuan tanah and kapitan, and members elected as representatives of the common people. It should be clear, however, that the Saniri Radjapatih possesses a strong voice within this larger body. Although not generally a numerical majority, it has the weight of status and tradition on its side. Although in theory the judgment of the radja and soa chiefs may be over-ridden, in practice this rarely happens. Yet sharp differences of opinion are frequent and are vigorously expressed.

In some villages, there are functional committees within the Badan Saniri Negeri, responsible for particular areas of concern. In Soja, for example, there are "departments" of health, roads and transportation, forests, and youth, which have supervision over these fields and are responsible for bringing to the saniri meetings any problems or projects which require policy decisions or collective action. This arrangement seems to be fairly recent. Perhaps it developed logically from the decline of the traditional offices of kéwang, mauweng and tuan tanah.

The Saniri Negeri Besar meets on those occasions when the whole electorate must be consulted. This "great saniri" consists of the Saniri Negeri Lengkap plus all males over eighteen years of age. (In practice, this means the heads of households.) It decides matters affecting the welfare of the entire village and requiring action by every family. At such meetings, assignments may be made to implement a decision already taken by the Saniri Negeri Lengkap or by the Saniri Negeri Besar itself. The meetings of the "great saniri" are preferably held in the baileu, if there is one. The saniri may also meet there when hearing cases of alleged violations of adat or civil law.

We have already commented on action by the Dutch government to broaden the base of the Badan Saniri Negeri by providing for the election of a member to represent each soa. Before that, there was only the Saniri Radjapatih and the Saniri Negeri Besar. It may be conjectured that in those days the Saniri Negeri Besar met more frequently than after the Dutch policy was put into practice.

One may observe that the structure of local government bears considerable resemblance to Guided Democracy, in the dominant role played by the radja and to a lesser extent the kepala soa, not only in the executive branch of government, but also in the legislative and judicial branches. ${ }^{32}$ "For all practical purposes,

32. In this sense there is some substance to Sukarno's contention that he had found the pattern for "Guided Democracy" in the indigenous political institutions of various Indonesian regions. 
it is the Saniri Radjapatih which governs," according to one village ruler. To characterize the situation thus is not to say that the other levels of government are simply empty forms or that there is no democracy in the Central Moluccas; it is merely to stress the prevailing tendency.

The Basis and Method of Constituting

Village Government

Despite all the changes which have occurred, heredity is still the predominant qualification for selection to the most important offices in the village government. In former times, following the rule of primogeniture, the eldest son of the incumbent usually succeeded to the father's position. This principle has now been modified to mere patrilineage heredity, that is to say, the person to be elected radja or kepala soa must come from a fixed mata rumah. Within the patrilineage, however, there is a considerable range of choice among possible candidates. The two positions for which the rule of primogeniture still generally applies are the tuan tanah and the kapitan. These officers, however, have already been shown to retain only ceremonial functions. Moreover, special preparation and training are needed to enable a person to perform even these remaining functions. This means that the successor must be trained by the incumbent before taking office. The principle of primogeniture, flexibly applied, admirably suits this situation.

Two factors have joined to promote this change from primogeniture to patrilineage heredity. The occasional lack of a candidate in the household of the incumbent meant that to keep the office within the prescribed mata rumah, it was necessary to select one of the other male relatives. Second, there were sometimes more able candidates in other households within the patrilineage than in that of the incumbent. Since it was important to have competent rulers and soa chiefs, it was best that they be chosen from among the more capable candidates. Ability has become the other dominant criterion for holding office.

The present method of selecting officers is illustrated by the selection of the Radja of Aboru in 1955. Oral, but private, nominations were received by the soa chief from his soa members. These nominations were passed on to the village council which transmitted the full list to the district office (kepala pemerintah setempat). After consideration by the district government, the list of candidates was announced in the village and the day of the election fixed. The district office supervised the election very closely. Votes were cast verbally, but in secret, each elector coming to the district officer and indicating his preference. The baileu is often used as a polling place, if this is suitable. It was not in Aboru, 
and so the church was used. The district officer conveyed the results to the Badan Saniri Negeri, which then announced them to the people, after which a date was set for the installation of the new official.

The change in the procedure for selecting officials illustrated here is very striking. It is one thing to fill offices by the automatic rule of primogeniture, or even by the incumbent choosing his successor from among his sons or close relatives. It is quite another matter to vest the nomination and election of new officials in the community at large, albeit only its adult males. ${ }^{3}{ }^{3}$ This is a notable demonstration of the tendency away from the autocratic tradition of the past and towards more democratically conceived institutions, a tendency which has accelerated since Independence.

\section{Duties of the Main Officers and the Village Council}

The pemerintah negeri, the village ruler, has two sets of duties or two points of reference for his responsibilities. He is responsible, in the first place, to the village community, that is, all those who have lived in the village, as well as those who at any given time reside there. In this regard, his duties and responsibilities are domestically oriented. But he is also acknowledged by the higher authorities and is, therefore, responsible to the district government for all matters under its jurisdiction.

As head of the village, the radja is ultimately responsible for the proper observance of the adat. ${ }^{34}$ He must, therefore, participate in, and be at the center of, all village ceremonies, as in the case of the annual purification rites, the péla renewal ritual and the receiving of the "cloth of blessing." The detailed guidance of these ceremonies rests with the kepala adat, or, in some cases, with the tuan tanah, but the radja is ex officio the over-all supervisor of the village adat.

The radja is also kepala saniri, which means that he presides at all meetings of the Badan Saniri Negeri at whatever level they take place. As chief executive in the village government, he holds the final power of decision and of implementing decisions, although he may delegate many of his functions to the officerof-the-month.

33. Of the total population of Aboru, circa 2,000, there were 530 adult males; 361 votes were cast in the election for radja held in June, 1955 .

34. Cooley, Ambonese Adat, p. 81 . 
The radja, traditionally, sat as chief judge in the village court. While this function has, at least formally, been withdrawn from village governments in the Moluccas, the radja and the kepala soa djaga bulan still adjudicate disputes, pass judgment on disciplinary matters, especially among the youth, and generally act as justices-of-the-peace. The radja also performs civil marriage ceremonies, a semi-judicial function.

The radja is charged with carrying out all functions delegated to the village government by the higher authorities. These include assessment and collection of taxes, issuing travel-passes to ships, supervision of public security, attendance in court in cases where information from the village is required, holding elections, and entertaining official visitors, either civil or military. In pre-war days, the radja from the more prominent villages were privileged to sit on the district-level court and advisory council, where they took part in reaching judgments on difficult cases of adat $l a w$ and in making policy-decisions affecting the villages. With the abolition of village courts and the change of venue of all civil and criminal cases to the seat of the district government, village rulers have been forced to leave the villages more frequently in order to attend court proceedings. This represents a general trend toward extending the duties of the village ruler outside his village as a result of the increasing centralization of power and authority in the larger administrative units of the civil government. Police asd court duties have been completely. transferred out of the village. At present, the legislative function is seldom practiced in the village because of the widening legislative scope of district and regional government. This trend will undoubtedly cause pronounced changes in the duties and responsibilities of village officers individually and of the Badan Saniri Negeri as a whole.

The soa chief has so far been characterized as an administrative assistant to the village ruler, but this description focusses primarily on his relation to the radja. He is essentially the headman of the soa, responsible for knowing what goes on within it, for leading his soa in completing its assignments on collective projects, for compiling vital statistics each year, and for collecting taxes. ${ }^{35}$ In effect, he governs his soa in much the same way that the radja governs his village. $\mathrm{He}$ is the channel through which a soa member can bring any concern to the attention of the village council. The elected member representing each soa can also serve as a channel for contact between the village council and the membership of the soa. The radja holds the kepala soa responsible for conditions

35. According to informants in one village, at the height of the colonial period, the soa chief was entitled to keep 8\% of the taxes he collected from the members of his soa. 
in his soa in the same way that the radja is himself held responsible by the higher authorities for conditions in the village.

Just as the radja's area of responsibility extends beyond the village, so the kepala soa's duties go beyond his own soa. He is a member of the Badan Saniri Negeri where he participates in all discussions and decisions regarding village affairs as a whole. And he takes a regular turn as officer-of-the-month. In this function, he assumes the day-to-day responsibilities of governing the village, with primary reference to domestic affairs, and the ruler is thus freed to attend to his wider responsibilities and oversee the general situation. The officer-of-the-month is addressed as Bapak Djou, bapak meaning father and djou being a title for ruler. ${ }^{36}$ This title of respect is applied to a kepala soa only when he is on monthly duty as second-in-command to the radja. A nominal stipend is given by the district officer for those months when a particular kepala soa serves as the special assistant to the radja. ${ }^{3}$ This description applies solely to the kepala soa akte, who are acknowledged by the higher authorities, and thus have duties affecting the entire village. The kepala soa masing serve as assistants to the kepala soa akte and the saniri as a whole, especially in matters of judicial counsel and general policy. They have no specific responsibilities but act as elder statesmen, rendering such services as are requested by the radja or kepala soa.

The marinjo is the soa messenger, errand-boy and minor police officer. He accompanies the soa chief on his monthly assignments as the ruler's assistant. He carries out the bidding of his superiors, carrying messages or summoning people to confront the village government, publicizing new decrees, delivering instructions, and announcing meetings. He is not a member of the Badan Saniri Negeri, but, in his official capacity, he usually attends the deliberations of the saniri and knows what transpires. He receives no remuneration, but his taxes, which amounted in 1960 to about 25 rupiah per year, are covered by the Saniri Radjapatih.

The kepala adat, the last major official, is somewhat different from the above-mentioned officers because his responsibilities are limited to one aspect of village life, the adat. $\mathrm{He}$ is the expert on all questions of adat law and ceremony. Usually he is a member of the Saniri Negeri Lengkap, though in some villages he sits with the saniri only when specially invited. He gives information, advice and instructions on adat matters to

36. E. Katoppo, Nuku (Bandung: Kilatmadju, 1957), p. 259, identifies it as a word from the East Indonesian regional vocabulary, meaning "a title used when speaking to or about the sultan." More precisely, it was used in Ternate, in the Northern Moluccas, and could well reflect Chinese influence. 
individuals, nuclear families, patrilineages, soa, or to the village council. In some villages, he also holds the title of tuan tanah, in others that of mauweng. He is the village adat officer, appointed by the ruler and approved by the Saniri Radjapatih, and usually holds office for life or until he becomes unable to fulfill the demands of his position. He receives no remuneration, though presents may be given him for his services. The adat chief generally leads village ceremonies, though in some cases he may be in the background directing other officers, such as the radja or tuan tanah, who are required by the adat to perform certain ceremonies.

In the most general terms, the saniri is charged with preserving and furthering the security and prosperity of the village community. This means, first and foremost, supervising and guaranteeing the carrying out of the adat, for only in this way, it is believed, can the favor and assistance of the ancestral spirits be won and the welfare of the village assured. The saniri is considered to be the living representative of the ancestors, hence it must oversee the fulfilment of the adat.

Another responsibility of village government is the defense of the community against dangers from within and without. The former usually take the form of encroachments on village territory, unauthorized occupation and exploitation of village or private land. Dangers from within most often take the form of friction and feuding between patrilineages or other groups over matters of land, marriage, or various prerogatives felt to be denied or slighted. If open conflict erupts, the village council must act speedily and wisely to restore harmony and peace. Ordinarily, however, matters are not permitted to reach this stage. The saniri will take measures to forestall the explosion by intervening and mediating the differences. The adat frequently provides special procedures for solving disputes.

The village government must also pay close attention to the general situation in order to fulfill demands and expectations of the village and press towards progress and welfare in all spheres. This includes, as in the example of Soja, provision for the general welfare in matters of health, sanitation, public works, education, water supply, discipline and wholesome recreation for the youth.

Finally, the saniri must implement the instructions and regulations issued by higher civil and military authorities. The village government is held responsible by district and regional officials in matters of taxation, security, and elections. The functions of village government which fall under this general heading are becoming more numerous and weighty at the present time, when the real power and authority of the Badan Saniri Negeri are being steadily weakened. 
How the Functions are Performed

A noticeably authoritarian pattern of leadership prevails in Moluccan society. Especially in the realm of village government, affairs are conducted by issuing commands. The radja summons the kepala soa djaga bulan, the marinjo, the kepala adat or the whole saniri by beating a drum. He issues an order to the kepala soa, who calls the marinjo and commands him to carry it out. The marinjo delivers the order and brings back the response. It is a hierarchical structure; orders come down from the top, with each level passing them on to the next lower level and passing the response or results back up to the top. In group interviews with the saniri, it was exceedingly difficult to get any free interchange between the members of the group. Questions were almost invariably answered by the ranking official present. Occasionally, others would make observations, usually in the form of elaborations, illustrations, or, very rarely, corrections. But to get them to discuss a problem among themselves was practically impossible, largely because of a constant awareness of status differences among the members.

The saniri uses strict methods to back up its authority and assure discipline on the part of the villagers. For improper conduct, especially on the part of youth, the rattan rod is liberally used. The radja or the officer of the month orders a certain number of strokes and the marinjo administers them in his presence. Cash fines are levied for violations of regulations. Forced labor, on the streets, in the village garden-plot or on the school grounds, may be required as punishment. In some villages, there are, or have been, detention-buildings, where offenders are held in isolation for varying periods of time. Traditional oaths are occasionally administered by the radja and adat chief to settle disputes or to investigate alleged misdeeds, such as adultery or alteration of land-boundaries. Because many Ambonese regard breaking an oath or perjury as an extremely grave offense, this method is particularly effective in revealing the true state of affairs. Today, most cases must be turned over to the police, who are seldom resident in the villages but must be called in. Formerly, almost all cases were handled within the Badan Saniri Negeri, but nowadays it only deals with minor affairs.

In general, village government continues to operate largely within the traditional pattern. Little imagination is applied toward meeting new conditions with new techniques of leadership, and there appears little evidence of foresight or initiative being used in solving needs and problems. Affairs are usually allowed to continue until circumstances force action to be taken. The observer's general impression is that the people, leaders as well as led, have a basically passive attitude. The village tends to await instructions from the district level. Villagers wait for leadership from the village council, and, if it is not 
forthcoming, they do nothing. After they elect new officials, they sit back to watch their performance. The colonial atmosphere strongly reinforced such tendencies, which were already present in the traditional pattern of social organization and action. The younger generation shows increasing impatience with such an environment and often chooses either to leave the village for the more dynamic atmosphere of towns and cities, or to introduce changes into the village which tend to aggravate existing tensions.

\section{Changes in the Institutions of} Village Government

The development of civil administration by the colonial power, especially during the nineteenth century, affected the pattern of village government in a number of ways. Local rulers were assiduously wooed by the colonial government as part of a policy of limiting and defining the power and functions of village government. The villages were autonomous so far as their ties with one another were concerned, but they cannot be said to have been independent.

In the 1920's, a regulation was promulgated that representatives were to be elected from each soa to positions in the village council. It was largely a formal step towards democracy, for the elected representatives did not possess much influence in the councils of the village, but it was nonetheless symbolically significant.

In addition, contact with the West brought Christianity, a new educational system, and a partial acculturation to the European style of life. The combined effect of these influences has been progressively to weaken and eventually to replace the indigenous religion. Many vestiges of this religion still remain, but its offices and institutions have largely been replaced by the institutions of Christianity and Islam. The tuan tanah is still to be found, but he retains only a fraction of his former position and power. The kepala adat is not an indigenous office; it is rather a composite office which has developed as the indigenous offices have declined.

There has been, in general, a pronounced weakening of the adat in Moluccan society. The village government system is based solidly on the adat, and one of its main functions is the supervision of the adat. If the adat becomes weaker, the institutions of village government are affected directly. This has undeniably already occurred to a large extent, though it is only beginning to be noticed or admitted by the Ambonese themselves.

Some offices within village government have disappeared altogether, while others have been weakened substantially and 
their functional significance severely limited. There has been a general loss of power, authority and prestige on the part of the village government as a whole, and of each of the offices which constitute it. A major blow to local government occurred when the 1950 Provisional Constitution of the Republic of Indonesia withdrew from village government the judicial functions which it had performed for centuries. Informants agreed almost unanimously that this was an important reason for the impotence of village government in the face of rapidly changing conditions, and a cause of declining respect for the government. They felt that this state of affairs was symbolized by the pittance the civil administration gives village officials for their services. No one wishes to be a radja or kepala soa under such circumstances, they said; it is all work and trouble, with no joy, respect or payment. Many of the most able younger leaders gravitate to the towns and cities, seeking higher education and employment in economic, government or other spheres where substantial status, remuneration, and personal satisfaction are within reach. Meanwhile, village government remains in the hands of people who cling to traditional ideas and who, until very recently at least, have shown little inclination or energy to cope with new situations.

It would be hazardous to predict in any detail what may develop in the future, but certain major trends seem clear. There is no reason whatever to expect a return to the previous state of affairs, something the ruling group in the village would welcome, but recognizes as unlikely. It is highly doubtful that the shift away from traditional patterns of village government, based on hereditary prerogatives and the adat, will cease. On the contrary, it is likely to be strengthened as the influence of modern ideas, until now largely limited to the national and regional levels, continues to penetrate into the villages. It seems quite possible that the village as an autonomous unit, with the right and power to govern itself in traditional terms, is on the verge of being eliminated through consolidation into larger units which will have the real policymaking and adjudicative functions. This has, in fact, already occurred to a pronounced degree. Village government can retain, at most, an administrative function, carrying out the laws and instructions of a district government in which the villages are to some degree represented. Under such conditions, the adat will increasingly be separated from government. It will continue to exist, but more in the form of acceptable custom than of a customary law enforced by village government. 
